\title{
Violação dos direitos e garantias individuais do contribuinte na atividade fiscalizadora da administração tributária
}

\author{
Violation of individual rights and guarantees in the activity of the taxpayer watchdog of tax \\ administration
}

Gabriel Gealh de Campos ${ }^{1}$

\begin{abstract}
Resumo
O presente estudo tem por objetivo fazer uma análise do poder de fiscalização que a Administração Tributária exerce sobre os contribuintes. 0 foco principal são os dispositivos infraconstitucionais que possibilitam ao Fisco ter acesso a dados sigilosos referente à movimentação financeira dos contribuintes, dispensada a autorização judicial. Conclui-se pela incompatibilidade das normas infraconstitucionais analisadas frente ao ordenamento jurídico pátrio, por entrarem em confronto com o estabelecido pela Constituição Federal no que tange às garantias e aos direitos individuais dos contribuintes.
\end{abstract}

Palavras Chave: Direitos e garantias individuais; Constituição Federal; Administração Tributária; Fiscalização; Tributos.

\begin{abstract}
This study aims to analyze the power of review that the Tax Administration has on taxpayers. The main focus are the infra devices that allow tax authorities have access to sensitive data relating to financial transactions of taxpayers, given judicial authorization. The results confirmed the incompatibility of the rules discussed infra front of the Brazilian legal order, by entering into conflict with the established by the Constitution with regard to guarantees and rights of individual taxpayers.
\end{abstract}

Keywords: Individual rights and guarantees; Constitution; Tax Administration Authority; Taxes.

\section{Introdução}

0 interesse da Fazenda Pública tem sido confundido com interesse público em razão da voracidade arrecadadora com a qual Administração Tributária tem exercido seu poder de fiscalização. Com isso os direitos e garantias individuais do contribuinte têm ficado

\footnotetext{
${ }^{1}$ Advogado. Discente da pós-graduação em Direito do Estado na Universidade Estadual de Londrina.
}

Revista de Direito Público, LondRINA, v. 4, N. 1, P. 219-235, Jan/ABr. 2009. 
em segundo plano, ao passo que a superação dos recordes de arrecadação passa a ser o fim último da Administração Tributária.

O legislador pátrio regulamentou o direito ao sigilo dos dados e das operações financeiras por meio de normas que fundamentam a atividade fiscalizadora da Administração Tributária, permitindo a consulta de dados protegidos pelos sigilos bancário e fiscal sem a autorização do Poder Judiciário.

0 presente trabalho irá analisar tais dispositivos legais, confrontando-os com as garantias e direitos fundamentais do contribuinte. Este confronto terá como paradigma a Constituição Federal, que condiciona a validade de qualquer norma infraconstitucional no ordenamento jurídico vigente.

\section{Direitos e garantias individuais do contribuinte}

O Estado de poder ou Estado de polícia caracteriza-se pela máxima segundo a qual o fim justifica os meios. Assim, desde que o governante alegue agir com finalidade de interesse público, o que, não raro, se confunde com interesse próprio, poderá atuar em relação aos indivíduos desprovido de qualquer parâmetro moral ou legalmente instituído, ignorando quaisquer direitos ou garantias individuais.

Em oposição, no Estado de Direito o governante, assim como qualquer indivíduo, deverá se submeter ao império da lei. No Estado de Direito é a lei que estabelece e tutela os direitos e garantias individuais que devem ser respeitados pelo Estado, ao buscar a consecução de seus fins.

É neste contexto que a Constituição Federal de 1988 estabelece expressamente em seu Art. 1ํ, que a "República Federativa do Brasil, constitui-se em Estado democrático e de direito". Logo, a Administração Tributária, seja na esfera federal, estadual ou municipal, ao fazer uso de suas competências tributárias, está obrigada a respeitar os direitos e garantias individuais, de forma que o contribuinte tenha o direito de, ainda que tributado pela pessoa política competente, ter respeitado seus direitos públicos subjetivos, constitucionalmente garantidos.

Evidente portando que os direitos e garantias individuais exercem-se em face do Estado, operando como barreira contra 0 arbítrio, contra 0 abuso de poder, contra 0 despotismo, contra 0 autoritarismo que a Constituição visa impedir. Não é por outra razão 


\section{Violação dos direitos e garantias individuais do contribuinte na atividade fiscalizadora da administração tributária}

que o capítulo I do título II da Constituição Federal de 1988 estabelece parâmetros segundo os quais as competências tributárias das pessoas políticas estão submetidas. Tais parâmetros constitucionais têm a finalidade de impedir que as pessoas políticas, ao exercerem suas competências tributárias violem as garantias e os direitos dos contribuintes, como a garantia à intimidade e à vida privada, ao sigilo de dados, ao devido processo legal, ao contraditório e a ampla defesa.

Na mesma linha do entendimento acima desenvolvido, Carraza (2007, p. 415) assim expõem acerca dos direitos individuais dos contribuintes:

Os direitos consagrados no art. 5ำ do Diploma Magno são tão ou mais relevantes do que os recebidos pela União, pelos Estados, pelos Municípios e pelo Distrito Federal para instituir impostos, taxas e contribuições de melhoria. Daí serem inconstitucionais as normas jurídicas que, a pretexto de exercitarem competências tributárias, impedirem ou tolherem o pleno desfrute dos direitos públicos subjetivos dos contribuintes.

O conjunto de direitos e garantias dos indivíduos diante da instituição, arrecadação e fiscalização de tributos é constitucionalmente estabelecido e forma o que a doutrina denomina de "estatuto do contribuinte", de acordo com Carrazza (2007, pp. 417-418).

0 estatuto do contribuinte exige que a tributação, livre de qualquer arbitrariedade, realize a idéia de Estado de Direito. Às várias possibilidades de atuação da Fazenda Pública há de corresponder à garantia dos direitos de cada contribuinte. Quanto mais gravosa a intervenção tributária, tanto mais cuidadosamente deverá ser protegida a esfera de interesses dos indivíduos.

Assim, o estatuto do contribuinte pressupõe que a Autoridade Administrativa se abstenha de qualquer arbitrariedade no exercício de suas competências, pois caso assim não proceda, entrará em conflito com a Constituição Federal na medida em que os direitos e garantias do contribuinte estariam violados.

Em suma, a tributação deve respeitar os parâmetros estabelecidos pela Constituição Federal, de forma a se eliminar o poder tributário absoluto do Estado. Não há outra forma de se atingir tal objetivo, senão respeitando os direitos e as garantias individuais do contribuinte. 


\section{Legislação infraconstitucional acerca do sigilo das operações de instituições financeiras}

Visando aparelhar o Estado de instrumentos jurídicos aptos a capacitá-lo a fazer valer o exercício do poder de fiscalização sobre os contribuintes, a Constituição Federal, nos termos do $\S 10$ Art. 145, facultou à Administração Tributária "identificar, respeitados os direitos e garantias individuais e nos termos da lei, o patrimônio, os rendimentos e as atividades econômicas do contribuinte".

Esse tópico vem analisar a legislação infraconstitucional que regula a matéria pertinente aos sigilos bancário e fiscal na movimentação financeira dos contribuintes a partir de 2001. As leis Complementares 104 e 105 de 2001, bem como a legislação que a regulamenta, constituem importantes instrumentos para que as Administrações Tributárias da União, dos Estados e dos Municípios possam identificar o patrimônio, os rendimentos e as atividades econômicas do contribuinte. Contudo, o que se demonstrará no neste tópico é que 0 § 1 ㅇdo Art. 145 da Constituição Federal não é respeitado na legislação em estudo, na medida em que vários de seus dispositivos afrontam os direitos e as garantias individuais do contribuinte.

O Art. 10 da Lei Complementar 105/2001 define taxativamente as espécies de instituição financeira que estão sujeitas à prestação de informações sigilosas. Segundo esse dispositivo, todas as empresas que movimentam valores ou dinheiro de terceiros são consideradas instituições financeiras, isso facilita a fiscalização e dificulta a elisão e evasão fiscal.

Contudo, há dispositivos controversos na Lei Complementar 105/2001, o que dificulta a interpretação e em alguns aspectos a torna inaplicável, ilegal ou, mesmo, inconstitucional. Cite-se a regra geral traçada no caput do Art. 10 dispondo que as instituições financeiras discriminadas no $\S 1^{\circ}$ deverão guardar sigilo de suas operações, e na seqüência, o § 30 do dispositivo em estudo cria várias exceções ao dever de sigilo. A maneira demasiadamente ampla na qual foram traçadas essas exceções descaracteriza o instituto do sigilo bancário e fiscal, pois abre a possibilidade ao Fisco de violar o sigilo das operações financeiras dos contribuintes, independentemente de autorização judicial. 


\title{
Violação dos direitos e garantias individuais do contribuinte na atividade fiscalizadora da administração tributária
}

Importante ressaltar que o dever de sigilo nas operações financeiras não é absoluto. Segundo a ordem constitucional pode-se violar o sigilo financeiro do contribuinte em casos de indício penal e por autorização do Poder Judiciário. Assim, deve ser conservado o sigilo das operações financeiras, excetuando-se os casos em que houver autorização judicial. As exceções abertas pela Lei Complementar 105/2001 autorizam que as instituições financeiras forneçam suas informações sigilosas diretamente à Autoridade Tributária, abolindo direitos e garantias constitucionais. Sobre o assunto, Pinto (2003, p. 255) pondera:

\begin{abstract}
Conclui-se que os dados bancários dos cidadãos não podem ser fornecidos pelas instituições financeiras por simples requerimento dos agentes do poder público, como dispõe a Lei Complementar 105/2001. Trata-se de dados invioláveis, devendo ser permitidas a solicitação de informações bancárias por parte dos agentes públicos às instituições financeiras e eventual quebra do sigilo bancário somente mediante autorização do Poder Judiciário. Tal fato só se justifica em casos de supremacia do interesse público sobre o particular, em virtude de flagrante indício de ilícito penal ou fiscal, ainda que esta lei permita. Haja vista configurar um direito e garantia individual do cidadão, que não pode ser alterado sequer por emenda constitucional, tampouco lei complementar, como tentou fazer o legislador.
\end{abstract}

O Art. $3 \cong$ da Lei Complementar 105/2001 regula as informações que deverão ser prestadas pelo Banco Central do Brasil, pela Comissão de Valores Mobiliários e pelas instituições financeiras quando solicitadas pelo Poder Judiciário.

Chama a atenção o § $3 \cong$ do Art. 3ㅇ da Lei Complementar 105/2001 ao dispor que 0 Banco Central do Brasil e a Comissão de Valores M obiliários fornecerão à Advocacia-Geral da União as informaç̧ões e os documentos necessários à defesa da União nas ações em que seja parte. Esse dispositivo cria uma discriminação no âmbito do processo judicial, na medida em que a União passa a ter acesso aos dados sigilosos do contribuinte, dispensada a autorização judicial, o que viola o princípio da ampla defesa do contraditório e do devido processo legal. Tal discriminação não se trata de uma prerrogativa, mas sim de um privilégio conferido ao interesse da União.

0 Art. 50 da Lei Complementar 105/2001 determina competir ao Poder Executivo disciplinar, inclusive quanto à periodicidade e aos limites de valor, os critérios segundo os quais as instituições financeiras informarão à Administração Tributária da União, as operações financeiras efetuadas pelos usuários de seus serviços.

$0 \S 10$ deste dispositivo aponta todos os tipos de operações que poderão ser utilizadas pela Administração Tributária na fiscalização de tributos, esse rol exaustivo de 
operações elencadas coaduna-se com o disposto no inciso VI do § 30 do Art. 1ำ da Lei Complementar 105/2001, que exclui do dever de sigilo bancário a prestação de informações nos termos e condições estabelecidos nos Arts. 2ำ 3ำ, 4ํ, 5ํ, 6ำ, $7^{\circ}$ e 9‥ Assim, não se configura violação do dever de sigilo o fornecimento das informações arroladas no $\S 10$ do Art. 5ㅇ da Lei Complementar 105/2001 ao Poder Executivo, dispensada a autorização judicial.

A redação do $\S 40$ deste dispositivo evidencia a dispensa de autorização do Poder Judiciário para que o Fisco tenha acesso a dados sigilosos dos contribuintes, na medida em que, recebidas as informações de que trata este artigo, se detectados meros indícios de falhas, incorreções ou omissões, ou de cometimento de ilícito fiscal, a autoridade interessada poderá requisitar as informações e os documentos de que necessitar, bem como realizar fiscalização ou auditoria para a adequada apuração dos fatos.

O Art. 50 da Lei complementar 105/2001 foi regulamentado pelo Poder Executivo por meio do Decreto 4489 de 22 de novembro de 2002. Este Decreto determina que as instituições financeiras devem prestar à Secretaria da Receita Federal informações sobre as operações financeiras efetuadas pelos usuários de seus serviços. Tais informações serão prestadas, continuamente, em arquivos digitais, de acordo com as especificações definidas pela Secretaria da Receita Federal, e restringir-se-ão a informes relacionados com a identificação dos titulares das operações e com os montantes globais mensalmente movimentados, relativos a cada usuário, vedada a inserção de qualquer elemento que permita identificar a sua origem ou a natureza dos gastos efetuados.

O Decreto 4489/02 dispõe ainda que a identificação dos titulares das operações ou dos usuários dos serviços será efetuada pelo número de inscrição no Cadastro de Pessoas Físicas (CPF) ou no Cadastro Nacional da Pessoa Jurídica (CNPJ) e pelo número ou qualquer outro elemento de identificação existente na instituição financeira. Caso a operação realizada pelo usuário não seja registrada em conta corrente, a instituição financeira deverá informar o número de registro ou de controle existente.

Nos termos dos Arts. 60 e 70 do Decreto 4489/02, ao receber as informações dos contribuintes, fornecidas diretamente pelas instituições financeiras, caso a Administração Tributária considere que detectou qualquer indício de falhas, incorreções ou omissões, ou de 


\section{Violação dos direitos e garantias individuais do contribuinte na atividade fiscalizadora da administração tributária}

cometimento de ilícito fiscal, a apuração dos fatos dar-se-á mediante a requisição dos elementos e dos documentos necessários.

Este mesmo Decreto dispõe ainda que seja facultada à Secretaria da Receita Federal a utilização dos dados obtidos diretamente das instituições financeiras, para instaurar procedimento fiscal tendente a verificar a existência de crédito tributário relacionado a impostos e contribuições sobre sua administração.

0 Art. 60 da Lei Complementar 105/2001 permite às autoridades e agentes fiscais tributários da União, dos Estados, do Distrito Federal e dos Municípios examinarem documentos, livros e registros de instituições financeiras, inclusive aqueles referentes a contas de depósito e aplicações financeiras, quando houver processo administrativo instaurado ou procedimento fiscal em curso e tais exames sejam considerados indispensáveis pela autoridade competente. 0 resultado dos exames, as informações e os documentos devem ser conservados em sigilo, observada a legislação tributária.

0 dispositivo em estudo estabelece um procedimento específico necessário à requisição das informações. Sem a devida instauração de processo administrativo ou procedimento fiscal em curso à Administração Tributária é vedado ter acesso aos documentos, livros e registros das instituições financeiras. Instaurado o procedimento, a Autoridade Administrativa solicitará inicialmente o extrato da conta bancária do contribuinte, em caso de recusa por parte do contribuinte, os documentos bancários serão solicitados diretamente às instituições financeiras.

0 disposto neste artigo não deixa dúvidas quanto à autoridade competente para instaurar o procedimento tendente a violar o sigilo do contribuinte, pois determina de forma clara que esta cabe aos agentes fiscais tributários da União, dos Estados e dos M unicípios. Contudo, a competência para violar o sigilo das operações financeiras é exclusiva do Poder Judiciário, a outorga de competência conferida no dispositivo em estudo às autoridades fiscais do Poder Executivo afronta o Art. 2 을 Constituição Federal ao dispor que "São Poderes da União, independentes e harmônicos entre si, o Legislativo, o Executivo e o Judiciário".

0 Art. 20 da Constituição Federal é violado exatamente no que tange ao princípio da reserva da jurisdição, pois 0 Art. $6 \cong$ da Lei Complementar 105/2001 atribui uma competência exclusiva do Poder Judiciário ao Poder Executivo, na medida em que o Art. 50, 
XII da Constituição determina que sigilo das operações financeiras é inviolável, podendo ser excepcionado somente por ordem judicial. Neste sentido Lenza (2008, p. 604) afirma que:

0 que se percebe, então, pela nova regra, é a quebra do sigilo bancário pela própria Receita Federal, dispensando- se o requerimento ao Poder Judiciário, 0 que, em nosso entender fere 0 Art. 5, XII, sendo a aludida lei indiscutivelmente inconstitucional, atribuindo um direito não estabelecido pelo constituinte originário.

0 Art. 6o da Lei Complementar 105/2001 foi regulamentado pelo Decreto 3724 de

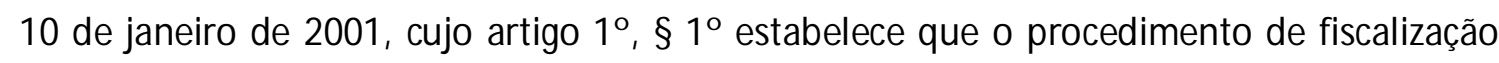
somente terá início por força de ordem específica denominada (Mandado de Procedimento Fiscal MPF), instituído em ato da Secretaria da Receita Federal do Brasil, ressalvado o dispositivo nos $\S \S 30$ e 4ㅇ do aludido dispositivo.

0 Art. 4ํ, $\S 10$, do Decreto estabelece ainda que a requisição será formalizada mediante documento denominado (Requisição de Informações sobre Movimentação Financeira RMF) e será dirigida, conforme o caso, ao a) Presidente do Banco Central do Brasil, ou a seu preposto; b) Presidente da Comissão de Valores Mobiliários, ou a seu preposto; c) presidente de instituição financeira, ou entidade a ela equiparada, ou a seu preposto; d) gerente de agência. 0 que se percebe é a quebra de sigilo bancário pela própria Receita Federal do Brasil, dispensando-se o requerimento ao Poder Judiciário, o que, fere 0 Art. 5o, XII da Constituição Federal.

De acordo com o Art. 198, caput do Código Tributário Nacional, em regra, a quebra do sigilo fiscal deve ser precedida de autorização judicial, expedida por solicitação de Comissão Parlamentar de Inquérito ou do Ministério Público. Além dessas situações, a Lei Complementar 104 de 10 de janeiro de 2001, dando nova redação ao Art. 198 do Código Tributário Nacional, especificamente no tocante ao texto contido em seu inciso II do $\S 1$ o e em seu $\S 2 \stackrel{0}{2}$, permite à Fazenda Pública a divulgação de informação que detém, por simples solicitação de autoridade administrativa no interesse da Administração Pública. Havendo a necessidade de ser comprovada a instauração de regular processo administrativo com objetivo de investigar o sujeito passivo a que se refere a informação, por prática de infração administrativa. 


\section{Violação dos direitos e garantias individuais do contribuinte na atividade fiscalizadora da administração tributária}

Essa alteração permite que a Administração Tributária divulgue informações relativas aos contribuintes independentemente de haver autorização judicial ampliando consideravelmente as exceções ao dever de sigilo fiscal, de acordo com Machado (2007, p. 276).

A Lei Complementar $\mathrm{n} \cong$ 104, de 10.1.2001, alterou a redação do caput do Art. 198 do CTN, e substituiu por três o seu parágrafo único, ampliando as exceções ao dever de sigilo fiscal. Na prática, pode-se dizer que já não existe o sigilo fiscal, pelo menos para impedir o que as autoridades da administração tributária mais gostam de fazer, que é utilizar a publicidade sensacionalista como forma de constranger 0 contribuinte.

Os dispositivos legais expostos neste tópico são objeto de questionamento perante - Supremo Tribunal Federal. Foram ajuizadas as ações diretas de inconstitucionalidade de $n$ o 2859-6, 2406, 2389, 2386, 2397 e 2390. Resta ainda saber o entendimento a ser dado pelo STF.

Nestas ações alega-se a inconstitucionalidade dos dispositivos legais acima expostos pelo fato de atribuírem direitos à Administração Tributária não estabelecidos pelo constituinte originário. Tal alegação tem fundamento no princípio da supremacia da Constituição, este princípio estabelece que a Constituição Federal é a norma fundamental do Estado, condicionando a validade de todo o ordenamento jurídico segundo seus princípios e normas. Silva (1992, pp. 47-49) assim define o princípio da supremacia da Constituição:

Pedra angular em que assenta o edifício do moderno direito político", "significa que a Constituição se coloca no vértice do sistema jurídico do país, a que confere validade e, que todos os poderes estatais são legítimos na medida em que ela os reconheça e na proporção por ela distribuídos. Ė enfim, a lei suprema do Estado, pos é nela que se acham as normas fundamentais de Estado, e só nisso se notará sua superioridade em relação às demais normas jurídicas.

Em decorrência do princípio da supremacia da Constituição, qualquer norma que viole as normas e os princípios estabelecidos pela Constituição Federal dever ser consequentemente excluída do ordenamento jurídico.

\section{Violação do direito à privacidade e à intimidade}

As informações bancárias e fiscais, sejam as constantes nas próprias instituições financeiras, sejam as constantes nos órgãos fiscais, constituem parte da vida privada da 
pessoa física ou jurídica. 0 sigilo de dados de operações financeiras deve ser compreendido como um desdobramento dos direitos à privacidade e à intimidade, assegurados no inciso $\mathrm{X}$

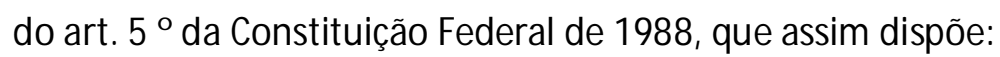

Art. 5 ‥ Todos são iguais perante a lei, sem distinção de qualquer natureza, garantindo-se aos brasileiros e aos estrangeiros residentes no País a inviolabilidade do direito à vida, à liberdade, à igualdade, à segurança e à propriedade, nos termos seguintes

X - são invioláveis a intimidade, a vida privada, a honra, e a imagem das pessoas, assegurado o direito a indenização pelo dano material ou moral decorrente de sua violação.

A inviolabilidade do sigilo bancário encontra respaldo na Constituição, não apenas pelo fato de os documentos bancários serem invioláveis, mas também por se tratar de uma proteção ao acesso de terceiro não autorizado à comunicação alheia, o que é inconciliável com a privacidade e a intimidade que a Constituição objetiva tutelar, de acordo com Bastos (1993, p. 63).

Não é possível atender -se tal proteção (intimidade) com a simultânea vigilância exercida sobre a conta bancária ou as despesas efetuadas com cartões de crédito pelo cidadão", pois "a doação feita a um partido político ou a uma seita religiosa (...) poderia ser identificada pelos órgãos fazendários que estariam desvendando uma vontade secreta do benemérito", e continua sua exposição dizendo "do atraso de pagamento da fatura de um cartão de crédito, ou de uma duplicata por dificuldades financeiras, ou da existência de saldo bancário desfavorável poderia ter ciência a União se houvesse a quebra do sigilo bancário e creditício, implicando, senão a comunicação a outros órgãos ou a adoção de medidas, ao menos 0 conhecimento de fatos relevantes e embaraçosos relativos à intimidade.

A natureza constitucional do direito à privacidade e à intimidade impõe, de acordo com o sistema normativo instituído pela Constituição Federal, a necessidade de intervenção jurisdicional no processo de revelação de dados pertinentes às operações financeiras de qualquer pessoa, seja ela física ou jurídica. Assim, a quebra do sigilo bancário ou fiscal só deve ser decretada, e sempre em caráter excepcional, quando existentes fundados elementos de suspeita que se apóiem em indícios idôneos, reveladores de possível autoria de prática ilícita por parte daquele que sofre a investigação.

Os dispositivos legais citados no tópico anterior permitem que a Administração Tributária, em âmbito federal, estadual e municipal, quebre o sigilo das operações 


\section{Violação dos direitos e garantias individuais do contribuinte na atividade fiscalizadora da administração tributária}

financeiras das pessoas físicas e jurídicas, ou ainda que esses dados, uma vez obtidos, sejam transferidos e circulem entre seus órgãos, ignorando os Direitos constitucionais à privacidade e à intimidade dos contribuintes.

O interesse público não pode ser confundido com o interesse da Fazenda Pública. Sendo assim, o afastamento da intervenção do Judiciário na concretização da medida excepcional da quebra do sigilo de dados bancários e operações financeiras desrespeita os fundamentos do Estado de Direito, na medida em que as garantias individuais tuteladas pela Constituição Federal são violadas pelo Estado para atender a seus interesses arrecadatórios.

Quaisquer órgãos do Estado ou qualquer Poder da República submetem-se, no exercício de suas prerrogativas constitucionais, às limitações impostas pela autoridade suprema da Constituição Federal. Dessa forma, a violação dos sigilos bancário e fiscal pela Administração Tributária não encontra respaldo no § $1^{\circ}$ do Art. 145 da Constituição. Ao contrário, o dispositivo constitucional faculta ao Poder Público, aferir a capacidade econômica do contribuinte, para fins de gradação dos impostos, identificando o patrimônio, os rendimentos e as atividades econômicas do contribuinte, ressalvando expressamente que, para tanto, deve-se respeitar os direitos individuais do contribuinte.

Em que pese a ressalva feita pelo legislador constituinte, na parte final do referido dispositivo constitucional, não se pode afirmar que as Autoridades Tributárias têm respeitado os direitos à privacidade e à intimidade dos contribuintes ao exercer os poderes de fiscalização conferidos pelas Leis Complementares 104 e 105 de 2001, sobre 0 assunto Carvalho (2003, p. 532) pondera que:

\footnotetext{
A experiência brasileira é testemunho eloqüente do uso da novel faculdade, mas antes disso 0 depoimento histórico aponta para 0 abuso dessa permissão, muitas vezes desenvolvida em termos de violação aos direitos da cidadania. Estamos em que, se alguma providência houvesse de ocupar o importante tópico, no quadro dos princípios gerais do Sistema Tributário Nacional, certamente hospedaria conteúdo oposto, qual seja 0 de firmar critérios mais seguros para a delimitação daquela vetusta faculdade, fortalecendo os direitos individuais e impedindo grosseiros atentados à ordem jurídica nacional.
}

A privacidade e a intimidade do contribuinte são Direitos fundamentais, sendo 0 sigilo bancário uma espécie deste gênero tutelado constitucionalmente. Assim, a violação do Direito ao sigilo bancário seja por parte de particulares, seja por parte do Estado no exercício 
da competência administrativa tributária, fere os Direitos e garantias individuais à privacidade e à intimidade dos contribuintes.

\section{Violação do direito ao sigilo de dados}

O Art. 5ํㅡ, XII da Constituição da República garante a inviolabilidade do sigilo da correspondência e das comunicações telefônicas, bem como dos dados pessoais, informatizados ou não:

Art. $5(\ldots)$

XII - É inviolável o sigilo da correspondência e das comunicações telegráficas, de dados e das comunicações telefônicas, salvo, no último caso, por ordem judicial, nas hipóteses e na forma que a lei estabelecer para fins de instrução processual penal.

A legislação infraconstitucional que dispõe acerca do sigilo de dados bancários é dotada de uma abrangência não contemplada pela norma constitucional em estudo. 0 Art. 50, XIl contempla apenas dois casos de inviolabilidade, 0 primeiro, 0 sigilo de correspondência e de comunicações telegráficas, em princípio absolutamente invioláveis e o segundo, o sigilo de dados. Esta segunda hipótese abrange o sigilo aos dados bancários e de comunicações telefônicas, em que a inviolabilidade seria relativa, mas sempre dependente de ordem judicial. A expressão sigilo de dados abrange o sigilo bancário, este é espécie daquele gênero. Assim, deve-se preservar o sigilo bancário do arbítrio, e admitir sua quebra somente quando houver autorização judicial.

A inviolabilidade do sigilo de dados, conforme disposto na Constituição Federal, torna essencial que as exceções derrogatórias à prevalência desse postulado só possam emanar de órgão do Poder Jurisdicional, ao qual a própria Constituição outorgou essa especial prerrogativa.

Neste sentido, a Lei Complementar 105/2001 viola a garantia constitucional ao sigilo de dados. A autorização judicial que exterioriza o exame imparcial da licitude do pedido, somente deve ocorrer na hipótese em que o interesse público assim o esteja exigindo e de que o sigilo esteja acobertando casos de sonegação evidente, e não de mero 


\section{Violação dos direitos e garantias individuais do contribuinte na atividade fiscalizadora da administração tributária}

palpite da fiscalização, como o permite a legislação infraconstitucional examinada.

Não se pode tolerar, portanto, que a fiscalização exija diretamente de terceiros, informações que apenas poderia obter do próprio contribuinte. Há hipóteses em que o interesse público deve prevalecer sobre o individual, mas caberá a um outro órgão estatal distinto da Administração definir se tais hipóteses efetivamente ocorrem. Caso convencido estiver o magistrado, diante de fatos comprovadamente apresentados, de que a hipótese é de gravidade de lesão ao interesse público, aí sim poderá o Poder Judiciário autorizar a quebra do direito ao sigilo bancário.

A garantia de que os sigilos bancário e fiscal sejam quebrados somente por determinação do Poder Jurisdicional, está constitucionalmente definida. Portanto, a norma que atribuir à Autoridade Administrativa Tributária o poder de requisitar informações diretamente às instituições financeiras, invade a reserva jurisdicional e agride a tripartição dos poderes prevista no Art. $2 \cong$ da Constituição Federal.

O legislador constituinte originário vedou a possibilidade de alterar ou eliminar a tripartição dos poderes, bem como os Direitos e garantias individuais dos contribuintes, na medida em que não se poderá emendar a Constituição Federal com tais finalidades.

Art. $60(\ldots)$

§40 Não será objeto de deliberação proposta de emenda tendente a abolir: (...)

III - a separação de poderes;

IV - os direitos e garantias individuais.

(...).

o Congresso Nacional não se encontra investido do chamado poder constituinte originário. Tal poder foi atribuído apenas à Assembléia Nacional Constituinte. 0 Congresso Nacional possui apenas o poder constituinte derivado que the permite emendar a Constituição, desde que não se oponha às cláusulas pétreas. As limitações formais e materiais expressas e implícitas, à competência que o Congresso Nacional possui para emendar a Constituição são uma garantia à manutenção do Estado de Direito. "Ignorar tamanhos desconchavos equivale a destruir o "estatuto do contribuinte" plasmado pela Constituição porque 0 Estado não teria mais nenhuma barreira, que não a própria voracidade, para tributar" Carrazza (2007, p. 453).

Prevalece na doutrina 0 entendimento de que qualquer informação relativa à 
movimentação financeira dos contribuintes encontra-se reservada sob a esfera de proteção do sigilo de dados, na condição de cláusula pétrea, de acordo com Pinto (2003, p. 249).

Ao interpretar a Lei Complementar 105 como se esta autorizasse a quebra do sigilo bancário pela autoridade administrativa fiscal estar-se-ia admitindo a violação de dados bancários. 0 fato de os dados serem bancários não significa que deixam de ser dados. Se são dados, trata-se de direito individual do cidadão e "cláusula pétrea" da Constituição Federal, não sendo permitido qualquer tipo de restrição a este direito, sequer por emenda constitucional, tendo em vista o disposto no inciso XII do Art. 5 o da CF.

Conclui-se pela inconstitucionalidade dos dispositivos infraconstitucionais em estudo, pois desrespeitam o Direito ao sigilo de dados, na medida em que as informações referentes à movimentação financeira dos contribuintes podem ser violadas pela Autoridade Tributária, sem a autorização judicial conforme determina a Constituição Federal.

\section{Violação do direito ao devido processo legal, ao contraditório e à ampla defesa}

As garantias do devido processo legal, do contraditório e da ampla defesa, constituem-se princípios constitucionais e, como tais, encontram fundamento nos incisos LIV e LV da Constituição Federal de 1988:

\footnotetext{
Art. 50 (...)

LIV - ninguém será privado da liberdade ou de seus bens sem o devido processo legal

LV - aos litigantes, em processo judicial ou administrativo, e aos acusados em geral são assegurados o contraditório e ampla defesa, com os meios e recursos a ela inerentes.
}

A Constituição Federal garante ao contribuinte em processo administrativo ou judicial contra a Administração Tributária paridade total de condições e plenitude de defesa, somente dessa forma o Direito ao devido processo legal, que tem como corolários a ampla defesa e o contraditório podem ser efetivos aos contribuintes.

0 princípio da ampla defesa possibilita aos litigantes em processo judicial ou administrativo condições que lhes permitam trazer ao processo todos os elementos que possam esclarecer a verdade. 


\section{Violação dos direitos e garantias individuais do contribuinte na atividade fiscalizadora da administração tributária}

Por sua vez, o princípio do contraditório impõe a condução dialética do processo, já que a todo fato argüido por uma das partes, a outra caberá igual direito de defesa ao oporIhe ou dar-Ihe versão que melhor the convenha.

0 contribuinte tem o Direito de ter apreciada a questão da violação dos sigilos bancário e fiscal pelo Poder imparcial por meio de decisão juridicamente fundamentada. A legislação infraconstitucional em estudo afronta o direito ao devido processo legal, ao contraditório e à ampla defesa, na medida em que os critérios autorizadores da violação do sigilo bancário pela autoridade fiscal não estão legalmente estabelecidos, pois foi atribuído à Autoridade Tributária o poder de violar os sigilos bancário e fiscal do contribuinte, tendo como limites critérios subjetivos.

0 próprio órgão do Poder Executivo, que é parte interessada, tem o poder de decidir sobre a quebra do sigilo do contribuinte, caso julgue ser indispensável. Estando em conflito o contribuinte e o Fisco, não poderia este decidir quais os documentos bancários sigilosos que são ou não indispensáveis, um terceiro imparcial é quem teria legitimidade para solucionar o conflito. A Constituição Federal estabelece que este terceiro somente pode ser órgão do Poder Judiciário.

O órgão da Administração Tributária não tem competência constitucional para decidir sobre a quebra dos sigilos bancário e fiscal, pois apenas o Poder Judiciário dispõe de efetivos meios para que o contribuinte possa se defender e apresentar provas, como expõe Baleeiro (1999, p. 1000).

Os demais poderes, quer se trate do Legislativo, quer do Ministério Público em investigação penal ou da administração Fazendária no lançamento e fiscalização dos tributos, não gozam nem poderiam gozar de livre acesso, incontrastável, às informações bancárias. A possibilidade de oposição e resistência do contribuinte, essência e núcleo da privacidade, seria nulificada se não fosse ouvido em juízo, ou se não pudesse opor defesa oportuna à pretensão fazendária ou a eventuais abusos em inquérito penal. Como núcleo essencial do Direito à privacidade e à intimidade de que o sigilo bancário é um mero desdobramento (Art., X e XII, da CF) configura a liberdade de negação, direito de resistência e de oposição do contribuinte à divulgação de dados pessoais, crescem de importância a defesa do contribuinte em juízo e o inteiro conhecimento prévio das pretensões do Fisco ou do Ministério Público, pois imprescindíveis e inerentes à própria garantia constitucional, sob pena de seu total esfacelamento.

0 art. 131 caput da Constituição Federal, define que a Advocacia Geral, deve representar a União judicial e extrajudicialmente, além de prestar consultoria e 
assessoramento jurídico ao Poder Executivo. Por sua vez, 0 § $3 \cong$ do Art. $3 \cong$ da lei complementar 105/2001, dispõe que o Banco Central do Brasil, a Comissão de Valores M obiliários ficam obrigados a fornecer, à Advocacia Geral da União todas as informações e documentos por esta solicitadas, necessários à defesa da União nas ações em que seja parte. Note-se que a legislação ignora o fato de tais dados estarem protegidos constitucionalmente pelos sigilos bancário e fiscal.

Esse privilégio concedido à Advocacia Geral da União, na condição de parte em juízo, representando o ente federal, agride o princípio da igualdade processual, desequilibrando a relação instaurada e desatendendo os examinados incisos LIV e LV do Art. $5 \cong$ da Constituição Federal. Tal desequilíbrio processual decorre da obtenção de dados sigilosos dos contribuintes por parte do Estado que segundo o texto constitucional, somente teria acesso a tais dados mediante autorização do órgão jurisdicional competente, fato este que impede o contribuinte de exercer seu direito constitucional ao contraditório e à ampla defesa.

É inconcebível no ordenamento jurídico brasileiro qualquer ameaça ou obstáculo à invocação da igualdade processual por parte de qualquer indivíduo. Contudo, a lei complementar 105/2001 confere essa possibilidade à União, por meio do Advogado Geral. Sempre que for parte interessada, poderá obter diretamente informações acerca de dados sigilosos de movimentação financeira dos contribuintes, sem necessidade de autorização judicial, violando a igualdade de tratamento que deve ser conferida às partes em juízo.

A Lei complementar 105/2001 retira do contribuinte o Direito de ter sua questão analisada de acordo com o devido processo legal, por órgão investido de competência jurisdicional, colocando-o à disposição da investigação, acusação, julgamento e condenação pela Autoridade Tributária, que é justamente o órgão do Poder Executivo interessado na quebra do sigilo bancário. Assim, o poder de julgamento é transferido à parte interessada, colocando no mesmo patamar acusador e julgador.

\section{Conclusões}

Os fundamentos apresentados no presente trabalho destinam-se a comprovar a induvidosa inconstitucionalidade do conteúdo da Lei Complementar $n \cong$ 105/2001 e dos decretos que a regulamentam, assim como do inciso II do $\S 1$ e e $\S 20$ acrescentados ao Art. 


\section{Violação dos direitos e garantias individuais do contribuinte na atividade fiscalizadora da administração tributária}

198 do CTN pela Lei Complementar $n \cong 104 / 2001$.

A referida legislação desrespeita os Direitos constitucionais da privacidade e da intimidade, do sigilo de dados, do livre acesso ao Judiciário, da igualdade de tratamento e da ampla defesa, todos relacionados no Título dedicado aos direitos e garantias individuais assegurados nos incisos X, XII, XXXV, LIV e LV do Art. 50 da Constituição Federal, como forma de expressão da liberdade evocada no caput do mesmo Art. 5o e sedimentada no texto constitucional como cláusula pétrea, a teor do disposto nos incisos III e IV do Art. 60 da Constituição Federal, a eles se reportando, expressamente, o § 1ํ do artigo 145.

0 respeito aos direitos e às garantias individuais constituem o pressuposto do Estado de Direito. Tolere-se a violação dos Direitos e garantias individuais em prol de um suposto "interesse público" e estará dado o primeiro passo rumo ao Estado de exceção.

\section{Referências}

BALEEIRO, Aliomar. Direito Tributário Brasileiro. Atualizado por DERZI, Misabel Abreu Macho. $11 \stackrel{a}{\varrho}$ ed. Rio de Janeiro: Editora Forense, 1999.

BASTOS, Celso. Estudos e pareceres de direito público. São Paulo; Revista dos Tribunais, 1993.

CARRAZA, Roque Antonio. Curso de Direito Constitucional Tributário. 23 a ed., São Paulo; M alheiros, 2007.

CARVALHO, Paulo de Barros. Curso de Direito Tributário. 15 a ed., São Paulo; Saraiva, 2003.

LENZA, Pedro. Direito Constitucional Esquematizado, 12 a ed. São Paulo; Saraiva.

M ACHADO, Hugo de Brito. Curso de Direito Tributário, 28 a ed. São Paulo; M alheiros, 2007.

PINTO, Fabiana Lopes. O Sigilo Bancário e a Lei Complementar 105/2001. Revista de Direito Tributário. São Paulo, 2003, n. 86, p. 239-275.

SILVA, José Afonso da. Curso de Direito Constitucional Positivo. 9 a ed. São Paulo; Malheiros, 1992. 